\title{
The motivational value of rewards amongst Malawi's health professionals
}

\begin{tabular}{|c|c|}
\hline \multicolumn{2}{|c|}{$\begin{array}{l}\text { Authors: } \\
\text { Alfred W.D. Chanza } \\
\text { Robin J. Snelgar } \\
{ }^{1} \\
\text { Gerrit J. Louw }{ }^{1}\end{array}$} \\
\hline \multicolumn{2}{|c|}{$\begin{array}{l}\text { Affiliations: } \\
{ }^{1} \text { Department of Industrial } \\
\text { and Organisational } \\
\text { Psychology, Nelson Mandela } \\
\text { Metropolitan University, Port } \\
\text { Elizabeth, South Africa }\end{array}$} \\
\hline \multicolumn{2}{|c|}{$\begin{array}{l}\text { Correspondence to: } \\
\text { Alfred Chanza }\end{array}$} \\
\hline \multicolumn{2}{|c|}{$\begin{array}{l}\text { Email: } \\
\text { nedchanza@yahoo.com }\end{array}$} \\
\hline \multicolumn{2}{|c|}{$\begin{array}{l}\text { Postal address: } \\
\text { Blantyre City Council, Private } \\
\text { Bag 67, Blantyre, Malawi }\end{array}$} \\
\hline \multicolumn{2}{|c|}{$\begin{array}{l}\text { Dates: } \\
\text { Received: } 07 \text { Jan. } 2013 \\
\text { Accepted: } 03 \text { June } 2013 \\
\text { Published: } 16 \text { Aug. } 2013\end{array}$} \\
\hline \multicolumn{2}{|c|}{$\begin{array}{l}\text { How to cite this article: } \\
\text { Chanza, A.W.D., Snelgar, } \\
\text { R.J., \& Louw, G.J. (2013). } \\
\text { The motivational value of } \\
\text { rewards amongst Malawi's } \\
\text { health professionals. SA } \\
\text { Journal of Human Resource } \\
\text { Management/SA Tydskrif vir } \\
\text { Menslikehulpbronbestuur, } \\
\text { 11(1), Art. \#517, } 14 \text { pages. } \\
\text { http://dx.doi.org/10.4102/ } \\
\text { sajhrm.v11i1.517 }\end{array}$} \\
\hline \multicolumn{2}{|c|}{$\begin{array}{l}\text { Copyright: } \\
\text { C) 2013. The Authors. } \\
\text { Licensee: AOSIS } \\
\text { OpenJournals. This wor } \\
\text { is licensed under the } \\
\text { Creative Commons } \\
\text { Attribution License. }\end{array}$} \\
\hline \multicolumn{2}{|l|}{ Read online: } \\
\hline 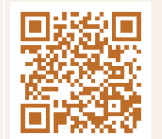 & $\begin{array}{l}\text { Scan this QR } \\
\text { code with your } \\
\text { smart phone or } \\
\text { mobile device } \\
\text { to read online. }\end{array}$ \\
\hline
\end{tabular}

Orientation: Reward administrators of Malawi's health sector seem to misunderstand the intrinsic and extrinsic values of financial and non-financial rewards.

Research purpose: This study focuses on assessing the motivational value of rewards amongst health professionals in Malawi's Ministry of Health $(\mathrm{MoH})$.

Motivation for the study: Malawian studies indicate that Malawi's $\mathrm{MoH}$ has become dysfunctional largely due to reward-related problems faced by its health professionals.

Research design, approach and method: This study was a non-experimental design with an explanatory and evaluative approach, utilising both quantitative (questionnaire) and qualitative methods (literature review, interviews and focus group discussions).

Main findings: The study confirmed the existence of reward-related problems amongst health professionals in Malawi's MoH. Initially, statistical testing of the hypothesised model collapsed, suggesting that no relationship existed amongst the variables. However, statistical testing of the re-specified model suggests that there is a positive relationship between financial and non-financial rewards. Through the structural equation modeling (SEM) exercise, an inverse (negative) relationship between financial and non-financial rewards was established.

Practical/managerial implications: The re-specified model symbolises a pragmatic departure from theoretical claims that financial rewards (salaries or money in general) are not a motivator. The graphic model suggests to managers and policy-makers that both financial and non-financial rewards are very important and valuable in any employment relationship.

Contribution/value-add: An inverse (causal) relationship between financial and non-financial rewards has been established, graphically demonstrated and scientifically explained.

\section{Introduction}

\section{Problem statement}

It seems Malawi's $\mathrm{MoH}$ is failing to attract, motivate and retain adequate health professionals (Bowie, Mwase \& Chinkhumba, 2009; Muula \& Maseko, 2005; Dovlo, 2003, 2004; Gordon, 2008; Manafa, McAuliffe, Maseko, Bowie, MacLachlan, Normand \& Chirwa, 2009; Ministry of Health, 2010; Mangham, 2007; Muula, 2006; Muula \& Maseko, 2005; Paradath, Chamberlain, McCoy, Ntuli, Rowson, \& Loewenson, 2003; World Bank, 2004). Various authors claim the following:

- Health professionals' perception of rewards is that they are inequitable (Gordon, 2008; Malawi Government, 2007; Manafa et al., 2009; Mangham, 2007; Muula \& Maseko, 2005; Palmer, 2006);

- Health professionals adopt financial coping strategies in their quest to supplement their monthly financial rewards (Bowie et al., 2009; Dovlo, 2003, 2004; Gordon, 2008; Manafa et al., 2009; Mangham, 2007; Muula \& Maseko, 2005; Tenthani, 2002);

- Health professionals engage in corrupt practices to supplement their monthly financial rewards (Chapalapata, 2011; Corruption in the Health Sector, 2010; Dzimbiri 2009; Khunga, 2011; Mangham, 2007; Ministry of Development Planning and Cooperation, 2010; Mphande, 2011; Munthali, 2011; Musa, 2011; Mzungu, 2011; Njiragoma, 2011);

- Industrial democracy is eroded in the Malawi's Public Health Sector (MPHS) (Dzimbiri, 2008; Van Klaveren, Tijdens, Hughie-Williams \& Martin, 2009, Phiri, 2007; Sonani, 2011).

Whilst the researcher acknowledges the availability of qualitative research reports revealing the existence of these reward-related problems, no comprehensive, quantitative and scientifically informed study has been conducted to substantiate them.

\section{Key focus of the study}

Various authors (Gordon, 2008; Manafa et al., 2009; Mangham, 2007; Mathauer \& Imhoff, 2006; McAuliffe, Bowie, Munafa, Maseko, MacLachlan, Hevey, Normand \& Chirwa, 2009; Mtazu, 2009; 
Muula, 2006; Muula \& Maseko, 2005; World Bank, 2004) claim that shortage of health professionals in Malawi's Ministry of Health $(\mathrm{MoH})$ is very severe even by African standards. This shortage mainly arises from reward-related problems and threatens the realisation of plans for scaling up interventions to control the spread of diseases in Malawi.

\section{Background to the study}

Health care in MPHS is highly labour intensive (Malawi Government, 2007; Mangham, 2007; Maseko, Nkunika \& Bowie, 2009; Mathauer \& Imhoff, 2006; McAuliffe et al., 2009; Ministry of Health, 2010; Mtazu, 2009; Muula, 2006; Muula $\&$ Maseko, 2005). The performance of this sector is critically dependent on worker motivation, defined as the degree of willingness of an individual worker to maintain an effort in his or her quest to achieve organisational objectives and goals; or a set of psychological processes and behaviours resulting from the transaction between individual workers and their work environment (Franco, Bennett \& Kanfer, 2002; Franco, Bennett, Kanfer \& Stubblebine, 2000; Franco, Bennett, Kanfer \& Stubblebine, 2004). Rewards (financial and nonfinancial incentives that employers offer to workers) are amongst the major determinants of worker motivation in the MPHS (Franco et al., 2004; Grobler, Warnich, Carrel, Elbert \& Hatfield, 2006; McAuliffe et al., 2009; Robbins, 2010).

\section{Trends from research literature}

Since the Hawthorne studies, whose findings demonstrate the importance of 'human relations' as a means of motivating employees, industrial and organisational psychologists have sustained an interest in understanding what motivates workers to perform to their greatest potential in the accomplishment of organisational vision, mission and goals (Berger \& Berger, 2000; Cole, 2000, 2004; Holbeche, 2010; Metcalf, 1995). Several authors (Agnew \& Redman, 1992; Ahlegren, Anderson \& Skold, 2007; Ariely, Bowey, Thorpe \& Hellier, 1986; Armstrong, 1993, 1999; Armstrong \& Murlis, 1998, 2007; Carrel, Elbert, Hatfield, Grobler, Marx \& Van der Schyf, 1998; Dittrich \& Carrel, 1979; Eddy, 2008; Swanepoel, Erasmus, Van Wyk \& Schenk, 2005) assert that to attract, motivate, satisfy and retain workers, business organisations invent (and provide to workers) financial and non-financial rewards in exchange for their efforts and performance in tandem with their respective employment contracts. However, the role psychological contracts play in an employment relationship is unknown.

\section{Aim and objectives of the study}

The aim of the study was to assess rewards and their motivational value amongst health professionals in Malawi's $\mathrm{MoH}$. The specific objectives of the study were as follows:

- To review the existing literature on rewards and motivation for workers with special attention to health professionals in Malawi's public health sector.

- Toassess the knowledge of a sample of health professionals regarding the rewards system(s) operational in Malawi's $\mathrm{MoH}$.
- To investigate the perceptions of a sample of health professionals about the efficiency and motivational value of the reward system(s) operational in Malawi's MoH.

- To investigate the perceptions of a sample of health professionals about the efficiency and motivational value of the financial rewards available in Malawi's $\mathrm{MoH}$.

- To investigate the perceptions of a sample of health professionals regarding the efficiency and motivational value of the non-financial rewards available in Malawi's $\mathrm{MoH}$.

- To substantiate the alleged reward-related problems faced by health professionals in Malawi's MoH.

- To suggest prescriptions for overcoming the rewardrelated problems faced by health professionals in Malawi's MoH.

- To determine how well the sample data fits a hypothesised model by using structural equation modelling (SEM) as a statistical method.

- To suggest a model that will help to bridge the gaps in the existing theories of rewards and motivation.

\section{Value of the study}

This research contributes to the theoretical knowledge of reward practices in the public health sector by expanding the body of knowledge about the value of financial and nonfinancial rewards as a means to attract and retain health professionals in the public health service domain. Therefore, various public health sector employers in Africa can use this study to guide the implementation of practices that motivate professionals to commit themselves to public health care services. The findings of this study could influence the decision-making processes regarding the introduction of efficient reward systems in the health sector in particular, as well as other public sector organisations in general.

\section{Literature review}

Rewards are defined as incentives provided by an employer for the time, skills and efforts made available by the worker in fulfilling job requirements aimed at achieving organisational objectives. In the context of this study, rewards are of two basic types. These are extrinsic (financial) and intrinsic (non-financial) rewards. Extrinsic rewards cover salary and all financial benefits (Bowie et al., 2009; Mullins, 1996; Muula, 2006; Muula \& Maseko, 2005; Swanepoel et al., 2005; Torrington, Hall \& Taylor, 2005). Intrinsic rewards consist of promotion, training and development, annual leave, maternity leave, sick leave, housing, company car, good working environment, club membership, annual award ceremonies to recognise employees' contributions, praise, delegation of work, job enrichment, job enlargement, participation in decision making, appreciation for personal contribution, giving employees a new or improved job title, celebrating the anniversary of their joining the company and a handwritten thank you note (Koala Consulting and Training, 2008; Manafa et al., 2009; Mullins, 1996; Muula, 2006; Muula \& Maseko, 2005; Snelgar, 2012; Swanepoel et al., 2005). 
Several authors claim that an effective reward system (procedures, rules, and standards associated with allocation of benefits and compensation to employees) takes on board both financial and non-financial rewards (Ahlegren et al., 2007; Armstrong, 1993, 1999; Bowey et al., 1986; Carrel et al., 1998; Eddy, 2008). Types of reward systems available to reward administrators are time-based (Bowey et al., 1986; Carrel et al., 1998; Eddy, 2008; Luczak, 1998; Pearce, Branyiczki \& Bakacsi 1994); competency-based (Carrel et al., 1998; Eddy, 2008; Ledford, 2008; Sparrow, 1996); and performancebased (Ahlegren et al., 2007; Beardwell \& Holden 2001; Bowey et al., 1986; Carrel et al., 1998; Eddy, 2008; Fowler, 1996; Mtazu, 2009). A time-based reward system (also known as basic rate system) is commonly used for jobs where workers are rewarded for actual hours worked or by the fraction of an annual rate of pay such as a week or a month (Carrel et al., 1998). Under a competency-based reward system, workers are paid for competences (knowledge, skills and aptitudes) they gain and apply when discharging their duties (Sparrow, 1996). Under a performance-based system, workers are rewarded according to their performance (Beardwell \& Holden 2001; Fowler, 1996).

Various authors (Armstrong, 1993, 1999; Basson, Christianson, Garbers, Le Roux, Mischke \& Strydon, 2002; Carrel et al., 1998; Cherrington, 1995; Dyer, Schwab \& Fossum, 1978; Ederer \& Manso, 2010; Goldthorpe, 1968; Holbeche, 2010; Howard, 1997; Kanfer, 1992; Ledford, 2008; Luczak, 1998; Pearce et al., 1994; Reid 2007; Rynes \& Gerhart, 2001; Singh, Das \& Dileep, 2006; Swanepoel et al., 2005) explain that the objectives of a reward system are to attract, motivate and retain adequate and highly qualified workers; to comply with legislative regulations including collective bargaining and to compensate workers for the labour services they render to their respective organisations.

There are three major schools of thought regarding rewards and motivation which have emerged in the field of industrial and organisational psychology. The first school views financial rewards as a primary motivator (Bowey, 1997; Feber \& Nelson, 2009; Gellerman, 1963; Robbins, 2010; Taylor, 1947; Weber, 1947). Financial rewards are a key in recognising workers' achievements and aspirations; reinforce desirable work behaviour; are a powerful means of informing workers what is actually valued or not valued in the organisation; are regarded by workers as highly tangible strategies for recognising their worth; and improve the workers' selfesteem and gain the esteem of others (Robbins, 2010). If financial rewards are inadequate, they can be a major source dissatisfaction and migration amongst workers (Armstrong, 2010; Armstrong \& Murlins, 2007; Duncan, Gruenburg \& Wallis, 1980; Greene, Caracelli \& Graham, 1989; Greenfield, 1993; Holbeche, 2010; Podger, 2002; Robbins, 2010; Stanley \& Berger, 1965). Robbins (2010) argues that the motivational value of financial rewards is greater than that of non-financial rewards because of their potential to meet various human needs advocated by Maslow (1943). 'People may not work for money [financial rewards], but take away the money [financial rewards], how many people would come to work?' (Robbins,
2010, p.180). In other words, financial rewards are a primary motivator in any employment relationship. Therefore, organisations have an obligation to use financial rewards to attract, motivate and retain workers. Workers use financial rewards to compare job offers since it is easier to compare financial (extrinsic) rewards as opposed to non-financial (intrinsic) rewards. Financial rewards play an important role in workers' decisions to join or leave an organisation (Armstrong \& Murlins, 2007; Baron-Punda, 2002; Caudron, 1993; Gellerman, 1963; Robbins, 2010; Taylor, 1947; Weber, 1947; Podger, 2002; Redmond, 2010). This school is backed up by classical theory which asserts that business organisations that have accepted this theory believe that workers are driven by the desire to earn maximum financial rewards. The theory's assumption is that workers are motivated primarily by financial rewards and will maximise their work output if they are offered extra financial rewards for any additional work (Feber \& Nelson, 2009; Gellerman, 1963; Robbins, 2010; Taylor, 1947; Weber, 1947).

The second school of thought supports the argument that the use of non-financial rewards as a primary motivator is important because they are effective when assignments require conceptual and creative thinking. Additionally, they are powerful in motivating positive work behaviour and building feelings of confidence and satisfaction amongst workers. Furthermore, the motivational value of non-financial rewards is long term and less costly than that of financial rewards (Cole, 2004; Landy \& Conte, 2010; Robbins, Odendaal \& Roodt, 2005; Snelgar, 2012). This school of thought is backed up by Herzberg's (1960, 1966) two-factor theory which describes factors such as achievement, recognition, increased responsibility, growth and development or advancement as motivators. Factors such as salary and other forms of financial rewards, company policies and administration, supervision, security, interpersonal relations and working conditions have been described as hygiene factors that do not motivate workers.

The third school of thought favours a well-balanced mixture of financial (extrinsic) and non-financial (intrinsic) rewards (depending on the situation and individual reward preferences) as a tool for motivating workers (Bowey, 1997; Dzimbiri, 2009; White, 1973). This school of thought is backed up by contingency theory, which asserts that reward preferences vary from individual to individual depending on individual differences and needs as well as prevailing forces in the wider environment (Blackburn \& Mann, 1979; Bowey, 1997; Burns \& Stalker, 1962; Woodward, 1958).

Franco et al.'s (2004) model, which partly forms the conceptual framework of this study, advocates for the use of both financial and non-financial rewards to bring about health worker motivation. It warns that financial rewards should be used with caution because, if applied excessively, they can lead to distortion in work effort. It also argues that financial rewards should be integrated with non-financial rewards and other interventions to create a more balanced approach to increase motivation, satisfaction and performance. 
The study focuses on assessing the motivational value of rewards amongst health professionals in Malawi's MoH in an effort to support the development of effective systems, practices and strategies that will improve the motivational value of rewards for the ministry's health professionals. It is theoretically structured around the above reward-related problems (refer to the whole 'Problem statement'), objectives of a reward system and schools of thought (in the 'rewardmotivation' debate) presented in this section.

\section{Method}

\section{Research approach}

The study was an explanatory and evaluative hybrid of quantitative and qualitative research approaches. The explanatory approach, which was quantitative in nature, covered the development and testing of hypotheses to explain the relationship amongst variables expressed under Sections B2 to E of the data collection instrument. This approach helped to scientifically investigate and explain the reward-related problems faced by health professionals (Babbie, 2004, 2005, 2007; Babbie \& Mouton, 2001; Collis \& Hussey, 2003; Berry, 2003; Burns, 2000; Clarke, 1995; Cresswell, 1994, 2009; DSS Research, 2001). The evaluative approach, on the other hand, was qualitative in nature, and covered a literature review, interviews, focus group discussions and administration of Section F of the data collection instrument, This approach helped to gain insights into and familiarity with the current 'reward-motivation' debate in the researcher's quest to appraise the application of models and theories of rewards and motivation in Malawi's MoH (Ader \& Mellenbergh, 2008; Decker, 1997; David \& Sutton, 2004; Alston \& Bowles, 1998).

\section{Research method Target population}

For this study, the population (sampling frame) consisted of all health professionals in Malawi's MoH. According to $\mathrm{Mr}$ Hillary Chimota, Controller of Human Resource Management and Development in Malawi's MoH (personal communication, 09 June 2011), 5707 out of 33376 health workers in the MPHS are health professionals on the ministry's payroll. These 5707 health professionals formed the population for this study because they belong to the core function or business of Malawi's $\mathrm{MoH}$ whilst the rest of the workers (27 669) are support staff belonging to the common service (support function) of the whole Malawi civil service.

\section{Sampling}

Ten percent $(10 \%)$ of the health professionals (i.e. 571 of 5707 of the ministry's health professionals) were systematically selected and became participants in the study. All (100\%) of these research participants completed and returned copies of the self-administered questionnaire. All elements of the population had equal representation in the frame.

\section{Data collection instrument}

A structured questionnaire was developed using the data collected from the desk research or literature review, focus group discussions and interviews.

The questionnaire had six sections, as follows:

- Section A contained biographic information of the respondents such as gender, age group, qualifications, registration with professional institutions, status of employment, and length of service (number of years working) with the $\mathrm{MoH}$ (refer to Table 1 for the rating or scoring of each sub-item).

- Section B1 aimed at assessing the respondents' knowledge of the reward system(s) (time-based or basic rate or performance-based or competence-based) operational in Malawi's MoH. Respondents were required to indicate 'Yes' (with a score of 1), 'No' (with a score of 2) or 'Don't

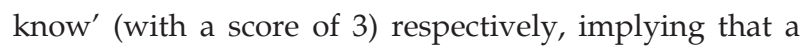
reward system was operational, not operational or that it was not known whether or not it was operational in Malawi's MoH.

- Section B2 aimed at assessing the knowledge and attitudes of respondents regarding the objectives of the reward system(s) operational in Malawi's MoH - whether it is able to attract the right health professionals for the right positions, retain the right health professionals for the right positions, motivate the right health professionals for the right positions, comply with the existing labour laws and policies, and compensate health professionals for services rendered.

- Section C aimed at assessing the opinions of the respondents regarding the motivational value of financial and non-financial rewards in Malawi's $\mathrm{MoH}$. Specific issues or items to be assessed were as follows: whether or not the respondents were primarily motivated by financial or non-financial rewards; whether or not the respondents essentially worked for financial or non-financial rewards; whether or not financial or non-financial rewards were adequate; whether or not financial or non-financial rewards were linked to performance; and whether or not current financial or non-financial rewards are able to drive the Ministry's productivity.

- Section D aimed at assessing the respondents' positions on the following alleged reward-related problems being faced by health professional in Malawi's MoH: the Ministry's failure to attract, motivate and retain adequate health professionals (five items); perception of inequity of rewards amongst health professionals (four items); development of coping strategies by health professionals to supplement their financial rewards (five items); health professionals' engagement in corrupt practices to supplement their financial rewards (five items); and erosion of industrial democracy in Malawi's MoH (five items).

- Section E aimed at assessing the respondents' positions on whether or not the suggested strategies under the 
following headings could help to address the rewardrelated problems faced by health professionals in Malawi's MoH in consonance with Section D: to attract, motivate and retain adequate health professionals by Malawi's MoH (six items); to ensure equity of rewards (seven items); to effectively manage coping strategies developed by health professionals (seven items); to eliminate corrupt practices (seven items); and to ensure industrial democracy (five items).

- Section F aimed at getting additional qualitative data from the respondents regarding reward practices for health professionals in Malawi's MoH through the following questions: apart from the reward-related problems mentioned in Section C, what other rewardrelated problems do health professionals in the $\mathrm{MOH}$ experience? What reward-related strategies should be developed and implemented to overcome reward-related problems faced by health professionals in Malawi's MoH? Comment on the future of Malawi's Public Health System if the current trend of rewarding health professionals remains unchanged.

For Sections B2, C, D and E of the questionnaire, statements that were used to measure the factors were scored on a five-point Likert-type scale. Thus, the scores for the item responses were on a scale of 1 to 5 as follows: strongly agree (with a score of 1 ), agree (with a score of 2), neutral (with a score of 3), agree (with a score of 4 ) and strongly disagree (with a score of 5). The questionnaire had not been used before. Pilot-studies were therefore conducted (followed by adjustments to the questionnaire) to improve its validity and reliability before administering it to the systematically sampled participants.

\section{Data collection procedure}

Empirical data were collected through the use a selfadministered questionnaire, focus group discussions and interviews. The questionnaire was composed using the data collected from desk research (literature review), focus group discussions and interviews.

\section{Data analysis}

Descriptive and inferential statistics were used to analyse quantitative data from the questionnaire. Such data were first coded and summarised before being entered into the computer using the Statistical Package for Social Science (SPSS) package (version 16). The package was chosen because of its convenience in analysing and interpreting data (Barry, 1998; Brace, Kemp \& Snelgar, 2000; Bryman \& Cramer, 1999; George \& Mallery, 2003; Salkind, 2000).

The statistical techniques used to analyse the data were item and factor analyses. Such analyses helped to determine whether or not items loaded significantly on the factors they were measuring. The analyses further helped to determine the internal consistency levels of the summated factor scores through the calculation of Cronbach's coefficient alphas as displayed in the 'results' heading below. The SEM technique was also used to test and estimate the causal relations amongst variables and determine the model fit for the hypothesised and re-specified models (Bentler, 1980, 1990; Hooper, 2008; Steven, 1991; Stevens, 1996).

The qualitative data collected from the questionnaire, supported by the existing literature, focus group discussions and interviews, were analysed manually using the 'content analysis' approach as recommended by research experts (Denzin \& Yvonnas, 2005; Oliver, 2010; Polit \& Hungler, 1995, 1999). The results derived from the use of qualitative data complemented and/or enhanced the inferences derived from the quantitative statistical analysis of the data. Several researchers (Babbie, 2004, 2007; Burns \& Grove, 2009; Cresswell, 1994, 2009; Korb, 2012; Mouton, 2009; Nicoll \& Beyea, 1997; Oliver, 2010) claim that with the complement of qualitative techniques, descriptive and inferential research techniques are useful in identifying problems with current practices and making judgements. Such techniques are also useful in determining what others in similar situations are doing. The findings of a study that has utilised quantitative inferential techniques are generalisable and replicable to the whole target population.

\section{Development of hypothesised model}

The relationships between factors were measured through a hypothesised model (a collection of logical relationships amongst variables or factors derived from theories and concepts) (Bentler, 1980, 1990; Steven, 1991; Stevens, 1996). Before testing, the model envisaged that objectives of a reward system have a significant mediating effect on the rewards and reward-related satisfaction of health professionals of MPHS. It further suggested that there is a good fit between exogenous or independent variables (financial and nonfinancial rewards) and endogenous or dependent variables (reward-related problems) with 'objectives of a reward system' as a mediating variable. The relationships amongst the variables in question are displayed in Figure 1.

In this context, an exogenous or independent variable refers to a factor or construct whose values (when manipulated by the researcher) creates effects on a dependent variable; a mediating variable refers to an intervening or intermediary factor or construct which is part of the causal chain; and an endogenous or dependent variable refers to a factor

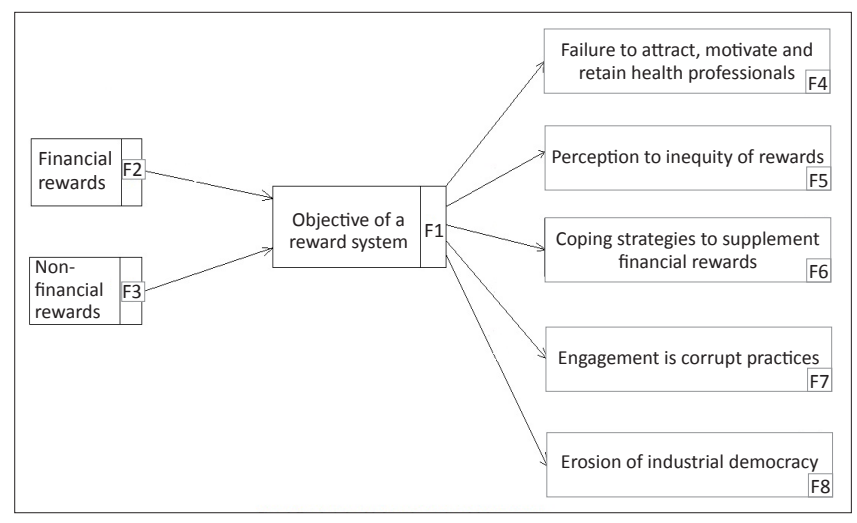

FIGURE 1: Hypothesised model of reward categories and their consequences. 
or construct whose value should be observed when an independent variable changes and represents a response, behaviour or outcome the researcher wishes to explain or predict (Gorsuch, 1983; Kim, 1995; Kim \& Mueller, 1978; Losh, 2002; Ratner, 2011; Routio, 2007). The hypothesised model, which was developed from theory (Armstrong, 1993, 1999; Bratton \& Gold, 2007; Koala Consulting and Training, 2008; Torrington, Hall \& Taylor, 2005), was statistically tested in the 'results' heading below.

\section{Results}

\section{Confirming reliability and validity of the questionnaire}

Reliability and validity of the questionnaire (research instrument) were confirmed as indicated in the following sub-sections.

\section{Trustworthiness \\ Reliability}

An item analysis was conducted in order to assess the reliability of the scores derived from the research instrument. Cronbach's coefficient alphas were calculated to determine the internal consistency of the instrument. All factors reported excellent reliability statistics. Cronbach's alphas, which ranged from 0.96 to 0.99 , exceeded the recommended threshold level of 0.70 for acceptable reliability, as displayed in Table 1.

Thus the item analysis results indicated that all factors had significant Cronbach's alpha values, suggesting very strong reliability and implying that they were all reliable for use in the study (Gliem \& Gliem, 2002). The internal consistency of the instrument was also tested and confirmed during the pilot studies at the following Malawian health facilities: Chiradzulu, Ntcheu and Kasungu District Hospitals (from 20 May 2011 to 08 July, 2011); Thyolo and Mulanje District Hospital (from 25 August 2011 to 29 August 2011); and Queen Elizabeth Central Hospital and Mwanza District Hospital (from 01 October 2011 to 11 November 2011). The results of the final pilot study produced coefficient alphas ranging between 0.72 and 0.94 .

\section{Validity}

To determine the validity of the instrument, a factor analysis with an oblique varimax rotation was conducted. The results showed a cumulated proportion of $90.30 \%$ which confirmed the validity of the questionnaire for use in this study. The item loadings for each factor were as follows:

- Factor 1: Items B2.1 (0.949), B2.2 (0.924), B2.3 (0.931), B2.4 (0.919) and B2.5 (0.944). This factor confirms a reward system's objectives of attracting, retaining and motivating workers; complying with the existing labour laws and policies; and compensating workers for the labour services they render to an organisation.

- Factor 2a: Items C1 (0.954), C2 (0.933) and C3 (0.970). This
TABLE 1: Item analysis results.

\begin{tabular}{|c|c|c|}
\hline Factor & Items & $\begin{array}{l}\text { Cronbach's } \\
\text { alpha value }\end{array}$ \\
\hline Factor 1: Objectives of a reward system(s) & B2.1-B2.5 & 0.97 \\
\hline $\begin{array}{l}\text { Factor 2a: Financial rewards (Importance of } \\
\text { rewards to health professional) }\end{array}$ & $\mathrm{C} 1-\mathrm{C} 3$ & 0.98 \\
\hline $\begin{array}{l}\text { Factor } 2 \mathrm{~b} \text { : Financial rewards (Assessment of } \\
\text { rewards provided by Ministry of Health) }\end{array}$ & C4-C5 & 0.98 \\
\hline $\begin{array}{l}\text { Factor 3a: Non-financial rewards(Importance of } \\
\text { rewards to health professional) }\end{array}$ & $\mathrm{C} 6-\mathrm{C} 8$ & 0.98 \\
\hline $\begin{array}{l}\text { Factor 3b: Non-financial rewards (Assessment } \\
\text { of rewards provided by Ministry of Health) }\end{array}$ & C9-C10 & 0.98 \\
\hline $\begin{array}{l}\text { Factor 4: Failure to attract, motivate and retain } \\
\text { health professionals }\end{array}$ & D1-D5 & 0.99 \\
\hline Factor 5: Inequity of rewards & D6-D10 & 0.99 \\
\hline $\begin{array}{l}\text { Factor 6: Coping strategies to supplement } \\
\text { financial rewards }\end{array}$ & D11-D14 & 0.98 \\
\hline Factor 7: Engagement in corrupt practices & D15-D19 & 0.96 \\
\hline Factor 8: Erosion of industrial democracy & D20-D24 & 0.96 \\
\hline $\begin{array}{l}\text { Factor 9: To attract, motivate and retain health } \\
\text { professionals }\end{array}$ & E1-E6 & 0.97 \\
\hline Factor 10: To ensure equity of rewards & E7-E13 & 0.98 \\
\hline $\begin{array}{l}\text { Factor 11: To effectively manage coping } \\
\text { strategies }\end{array}$ & E14-E20 & 0.99 \\
\hline Factor 12: To eliminate corrupt practices & E21-E26 & 0.99 \\
\hline Factor 13: To ensure industrial democracy & E27-E31 & 0.99 \\
\hline
\end{tabular}

factor confirms the use of financial rewards as motivators in organisations.

- Factor 2b: Items C4 (0.937) and C5 (0.914). This factor also confirms the use financial rewards as motivators in organisations.

- Factor 3a: Items C6 (0.942), C7 (0.948) and C8 (0.965). This factor confirms the use of non-financial rewards as motivators in organisations.

- Factor 3b: Items C9 (0.979) and C10 (0.972). This factor also confirms the use non-financial rewards as motivators in organisations.

- Factor 4: Items D1 (0.957), D2 (0.913), D3 (0.979), D4 (0.897) and D5 (0.975). This factor confirms the failure of Malawi's MoH to attract, motivate and retain health professionals.

- Factor 5: Items D6 (0.896), D7 (0.852), D8 (0.876), D9 (0.918) and D10 (0.958). This factor confirms the inequity of rewards amongst health professionals in Malawi's $\mathrm{MoH}$.

- Factor 6: Items D11 (0.920), D12 (0.942), D13 (0.924) and D14 (0.958). This factor confirms that health professionals in Malawi's MoH develop coping strategies in their quest to supplement their monthly incomes.

- Factor 7: Items D15 (0.909), D16 (0.863), D17 (0.932), D18 (0.886) and D19 (0. 912). This factor confirms the engagement of health professionals in corrupt practices in their quest to supplement their monthly financial rewards.

- Factor 8: Items D20 (0.907), D21 (0.844), D22 (0.897), D23 (0.923) and D24 (0.938). This factor confirms the erosion of industrial democracy in Malawi's MoH.

- Factor 9: Items E1 (0.892), E2 (0.950), E3 (0.936), E4 (0.860), E5 (0.950) and E6 (0.862). The implementation of the items in this factor is confirmed in order to attract, motivate and retain health professionals in Malawi's $\mathrm{MoH}$.

- Factor 10: Items E7 (0.822), E8 (0.911), E9 (0.938), E10 (0.913), E11 (0.946), E12 (0.942) and E13 (0.961). The 
implementation of the items in this factor is confirmed in order to overcome the inequity of rewards amongst health professionals in Malawi's MoH.

- Factor 11: Items E14 (0.961), E15 (0.976), E16 (0.958), E17 (0.945), E18 (0.954), E19 (0.955) and E20 (0.963). The implementation of the items in this factor is confirmed in order to effectively manage the coping strategies adopted by health professionals in their quest to supplement their monthly financial rewards.

- Factor 12: Items E21 (0.989), E22 (0.971), E23 (0.961), E24 (0.980), E25 (0.971) and E26 (0.946). The implementation of the items in this factor is confirmed in order to eliminate corrupt practices amongst health professionals in Malawi's MoH.

- Factor 13: Items E27 (0.968), E28 (0.981), E29 (0.984), E30 (0.962) and E31 (0.975). The implementation of the items in this factor is confirmed to ensure/improve industrial democracy in Malawi's MoH in particular and Malawi's public health sector in general.

Some authors (Fabrigar, Wegener, MacCallum \& Straham, 1999; Wikipedia, 2012) recommend a loading of 0.7 or higher to confirm that an item represents a particular factor in a research instrument. The above results indicate high loadings (of equal to or greater than 0.822 ) for all items making up each factor confirming validity of the whole research instrument.

Descriptive statistics for biographical characteristics of the respondents.

Five hundred and seventy-one (i.e., $n=571$ ) health professionals sampled for the study completed the questionnaire. The figure represents $100 \%$ of the selected study sample. For this reason, ' $n=571^{\prime}$ for every finding in this study. Therefore, ' $n=571$ ' will not be specified when presenting every finding to avoid unnecessary repetition. Descriptive statistics for biographical data included gender, age, qualifications, registration, status of employment and length of service, as displayed in Table 2.

In Table 2, approximately $25.74 \%$ and $74.26 \%$ of the respondents were males and females respectively. Thus the study was female-dominated (74.26\%). The majority of the female health professionals are in the nursing field (H. Chimota, personal communication, 09 June 2011; Ministry of Health, 2011; National Statistical Office, 2008).

Whilst there was no respondent in the age group below 20 years, 139 respondents $(24.35 \%)$ were between 20 and 29 years. The majority of the respondents $(65.67 \%)$ were in the '30-39 years' age group. The number of the respondents drastically declined with the increase in age. The '40-49 years' age group had 39 respondents (6.83\%) and there were 16 respondents $(2.80 \%)$ in the '50-59 years' age group. The '60 years or older' age group had two respondents $(0.35 \%)$ only.

All of the respondents $(100 \%)$ were qualified health professionals. Approximately $12.78 \%$ and $42.38 \%$ of the respondents were degree and diploma holders respectively
TABLE 2: Biographical characteristics of the respondents.

\begin{tabular}{|c|c|c|c|c|}
\hline Score & Variable & Characteristics & Frequency & $\%$ \\
\hline 1 & Gender & Male & 147 & 25.74 \\
\hline 2 & & Female & 424 & 74.26 \\
\hline 1 & Age group & Below 20 years & 0 & 0.00 \\
\hline 2 & & $20-29$ years & 139 & 24.35 \\
\hline 3 & & 20-39 years & 375 & 65.67 \\
\hline 4 & & $40-49$ years & 39 & 6.83 \\
\hline 5 & & $50-59$ years & 16 & 2.80 \\
\hline 6 & & 60 years or older & 2 & 0.35 \\
\hline 1 & Qualifications & Degree & 73 & 12.78 \\
\hline 2 & & Diploma & 242 & 42.38 \\
\hline 3 & & Below diploma & 256 & 44.84 \\
\hline 4 & & $\begin{array}{l}\text { Number of registered } \\
\text { health professionals }\end{array}$ & 571 & 100.00 \\
\hline 1 & $\begin{array}{l}\text { Registration with } \\
\text { professionals institutions }\end{array}$ & $\begin{array}{l}\text { Medical Council of } \\
\text { Malawi }\end{array}$ & 310 & 54.29 \\
\hline 2 & & $\begin{array}{l}\text { Nurses and Mid-wives } \\
\text { Council of Malawi }\end{array}$ & 238 & 41.68 \\
\hline 3 & & $\begin{array}{l}\text { Pharmacy, Medicines } \\
\text { and Poisons Board }\end{array}$ & 23 & 4.03 \\
\hline 1 & State of employment & $\begin{array}{l}\text { Permanent health } \\
\text { professional }\end{array}$ & 529 & 92.64 \\
\hline 2 & & $\begin{array}{l}\text { Temporary health } \\
\text { professional }\end{array}$ & 0 & 0.00 \\
\hline 3 & & Probationer & 41 & 7.18 \\
\hline 4 & & $\begin{array}{l}\text { Contract health } \\
\text { professional }\end{array}$ & 1 & 0.18 \\
\hline 1 & Length of service & $0-1$ year & 0 & 0.00 \\
\hline 2 & & $2-4$ years & 143 & 25.05 \\
\hline 3 & & $5-9$ years & 374 & 65.50 \\
\hline 4 & & $10-19$ years & 38 & 6.65 \\
\hline 5 & & 20 years and above & 16 & 2.80 \\
\hline
\end{tabular}

whilst $44.84 \%$ of them had qualifications below diploma level. This finding implies that all respondents were exposed to formal health professional training and were qualified to work in the health facilities under Malawi's $\mathrm{MoH}$. Furthermore, all of the respondents indicated that they were duly registered with their respective professional institutions: Medical Council of Malawi (54.29\%); Nurses and Mid-wives Council (41.68\%); and Pharmacy, Medicines and Poisons Board (4.04\%).

The respondents were requested to indicate their status of employment in Malawi's MoH (whether they were permanent, temporary, probationary or contract employees). Five hundred and twenty-nine (529) respondents (92.64\%) were permanent health professionals, 41 respondents $(7.18 \%)$ were probationers and one respondent $(0.18 \%)$ was a contract health professional.

The respondents were also requested to indicate their length of service with the $\mathrm{MoH}$. There was no respondent in the '0-1 year' category; $143(25.05 \%)$ in the ' $2-4$ years' category; 374 $(65.50 \%)$ in the ' $5-9$ years' category; 38 (6.65\%) in the ' $10-19$ years' category; and $16(2.80 \%)$ in the '20 years or older' category.

\section{Statistical analysis}

Statistical analysis was carried out to test the hypothesised and re-specified models as discussed in the following subsections. 


\section{Hypothesis testing}

One of the hypotheses formulated and tested in this study was that objectives of a reward system have a significant mediating effect on rewards and reward-related satisfaction of health professionals of MPHS. This hypothesis suggests that there is a good fit between financial rewards, nonfinancial rewards and reward-related problems (represented by attraction, motivation and retention; non-corrupt practices; equity of rewards; financial coping strategies; and industrial democracy) when mediated by the reward system's objectives.

In terms of theory (Armstrong, 1993, 1999; Bratton \& Gold, 2007; Koala Consulting and Training, 2008; Torrington et al., 2005), the objectives of a reward system mediate or strengthen the motivational value of financial and non-financial rewards to counter reward-related problems (mentioned in the 'problem statement and research objectives' section). In this study, the researcher's proposed model (refer to Figure 1) was based on theory and tested by means of the SEM technique in consonance with former research publications (Bentler, 1980, 1990; Fan Thompson \& Wang, 1999; Hooper, 2008; Steven, 1991; Stevens, 1996). However, the analysis of the model (through the SEM exercise) collapsed suggesting that the sample in this study does not support the measurement model. It could be interpreted that the objectives of a reward system do not have a mediating effect in addressing reward-related problems through financial and non-financial rewards in Malawi's MoH. The hypothesis was therefore rejected. Consequently, the mediating factor (objectives of a reward system) was omitted when developing and testing a re-specified model, presented below.

\section{The re-specified model}

Some researchers (Bagozzi, 2012; Goldberger, 1972; Pearl, 2000) assert that whenever necessary, a model must be modified (re-specified) to improve the fit and estimate the most likely relationships between variables. Modifications that improve model fit should be treated as potential changes made to the model. In addition to improvements in the model fit, the modifications (re-specifications) should also make theoretical sense. Hooper (2008) and Kenny (2011) agree that when a model has been re-specified, any modifications made and correlations (causal relations) between variables must be reported. It is against the professional advice of some researchers (Bagozzi, 2012; Goldberger, 1972; Hooper, 2008; Kenny, 2011; Kerliger \& Lee, 2000; Pearl, 2000) that the re-specified model (and correlations between the variables) was reported in this study. Objectives of the reward system were omitted from the re-specified model and consequently the SEM exercise produced significant results from the respecified model with several explanations. Figure 2 displays the re-specified model followed by explanations of the causal relationships amongst the variables.

In Figure 2, it is clear that there are positive causal relationships (correlations) between financial rewards and reward-related problems faced by health professionals in
Malawi's MoH. The weakest correlation exists between financial rewards and erosion of industrial democracy. The strongest association (with a coefficient of 0.46 ) exists between financial rewards and failure to attract, motivate and retain health professionals followed by the correlation between financial rewards and perception of inequity of rewards (with a value of 0.45 ). The value of the correlation between financial rewards and coping strategies to supplement financial rewards is 0.44 , whilst the value of the correlation between financial rewards and engagement in corrupt practices is 0.26 . The results confirm that there is a positive relationship between financial rewards and alleged reward-related problems being faced by health professionals in Malawi's MoH. These results are statistically significant $(p<0.05)$ (Hooper, 2008) and imply the following:

- Inadequate financial rewards have resulted in the failure of Malawi's $\mathrm{MoH}$ to attract, motivate and retain staff.

- There is a perception of inequity of rewards amongst health professionals in Malawi's $\mathrm{MoH}$.

- Health professionals develop and use coping strategies to supplement their financial rewards.

- Health professionals engage in corrupt practices to supplement their financial rewards.

- There is an erosion of industrial democracy in Malawi's $\mathrm{MoH}$ due to inadequate financial rewards.

Qualitative responses (from both male and female respondents, married and not married within the '20 to 49 years' age range) captured under Section F of the questionnaire were reported verbatim as follows:

- 'Brain drain will continue to torment Malawi's MoH if the Malawi government is not serious in managing the HR crisis created by inadequate rewards provided to health professionals'.

- 'Health professionals will continue to take up job opportunities in the global market as demand for their expertise rises in high income areas'.

Qualitative responses captured during interviews and focus group discussions were coded, paraphrased and summarised as follows:

- If financial rewards for health professionals are not market-driven, policy-makers should not be surprised with the massive exodus of health professionals from Malawi's Ministry of Health.

- Health professionals find it frustrating to receive lower financial reward packages than expatriate technical support staff with the same or lesser qualification and experience.

The quantitative findings (supported by the qualitative responses) confirm the motivational value of financial rewards, which is an academic departure from Herzberg's (1960, 1966) two-factor theory which regards financial rewards as a hygiene factor and not a motivator.

Various researchers (Bentler, 1980, 1990; Hooper, 2008; Steven, 1991; Stevens, 1996) advise that when selecting model fit statistics to report, the researcher should simply report the statistics that estimate the best fit. Other researchers (Fan, 


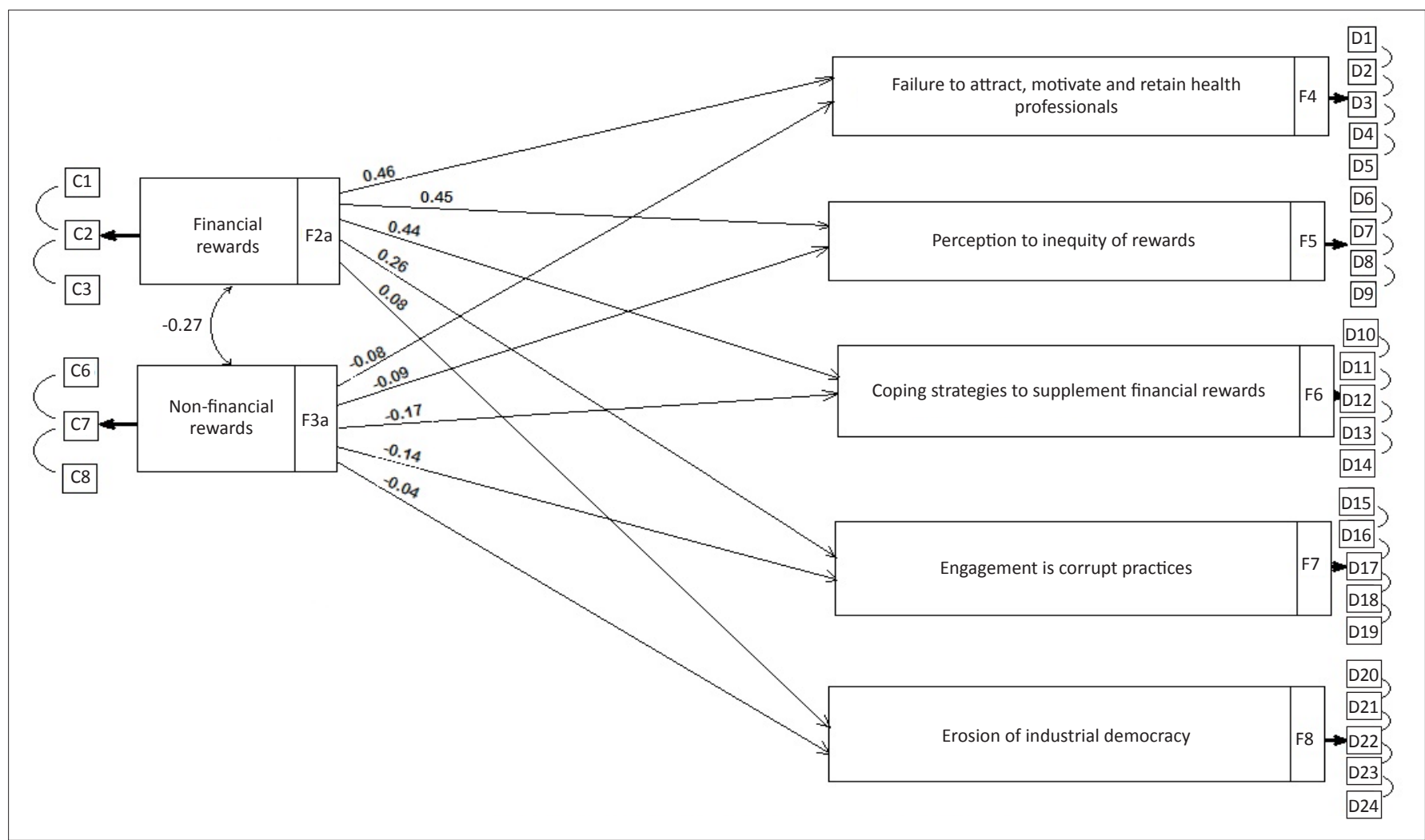

FIGURE 2: The re-specified model displaying corrections between variables.

Thompson \& Wang, 1999; Kerlinger \& Lee, 2000) caution that several fit statistics must be consulted when evaluating a model fit because fit indices were developed for different rationales. No single fit meets all expectations of an ideal index. In consonance with this advice, a factor analysis was conducted to determine the model fit. Consequently, the statistical measures that estimated the reasonable fit between the proposed model and the empirical data were a normed fit index (NFI), (Bentler \& Bonnet, 1980) with a value of 0.86; a non-normed fit index (NNFI) (Bentler \& Bonnet, 1980) with a value of 0.86; and a comparative fit index (CFI), (Bentler, 1990) with the value of 0.88 .

Deducing from Figure 2, this researcher has established an inverse relationship (negative correlation) between financial rewards and non-financial rewards as graphically demonstrated in Figure 3.

In the graph presented in Figure 3, the horizontal axis denotes financial rewards (FR) whilst the vertical axis denotes nonfinancial rewards (NFR). The NFR-FR line or curve represents the relationship between non-financial rewards and financial rewards.

Theoretically, the graphic model shows that, ceteris paribus, health professionals with initial financial rewards at $\mathrm{FR}_{0}$ will demand initial non-financial rewards at $\mathrm{NFR}_{0}$ from the employer (i.e., Malawi's MoH). If financial rewards are increased by the employer to $\mathrm{FR}_{1}$, demand for non-financial rewards by health professionals will decrease to $\mathrm{NFR}_{1}$. If financial rewards are decreased by the employer to $\mathrm{FR}_{2}$, demand for non-financial rewards by health professionals

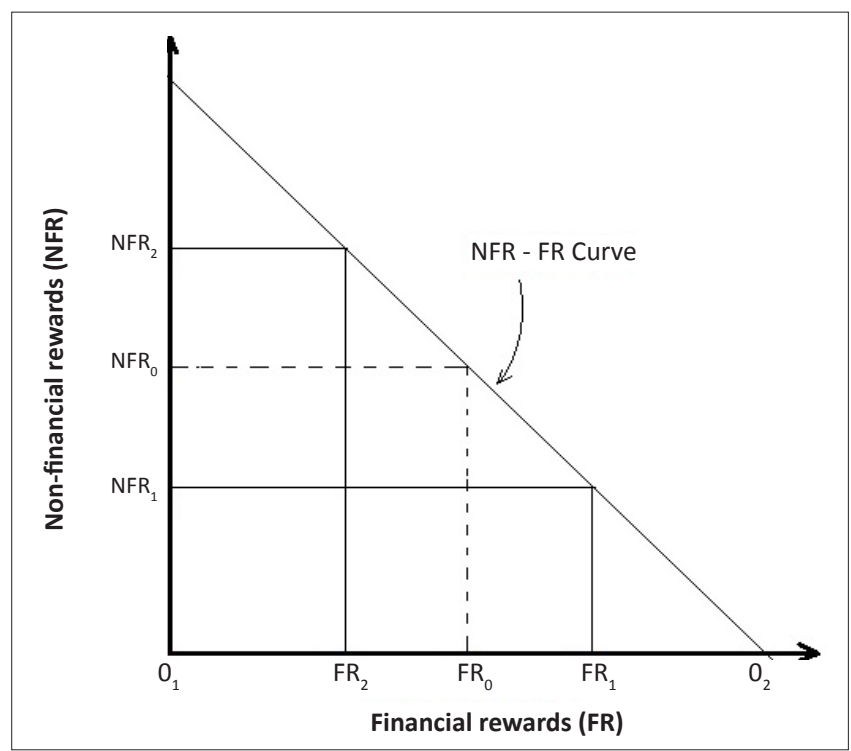

FIGURE 3: Relationship between financial and non-financial rewards.

will increase to $\mathrm{NFR}_{2}$. Decreasing financial rewards to $0_{1}$ by the employer implies the end of the employment contract and demand for non-financial rewards by health professionals disappears. On the other hand, increasing financial rewards to $\mathrm{O}_{2}$ will result in zero demand for non-financial rewards by health professionals.

This researcher is of the opinion that the graphic model displayed in Figure 3 is a true reflection of what happens in the real world of work especially in developing countries where the frequently cited non-financial rewards have 
financial implications. These are housing or accommodation or shelter, training opportunities, development opportunities, promotional opportunities, company car, good working environment, club membership and annual award ceremonies to recognise employees' contributions (Armstrong \& Mullins, 2007; Carrel et al., 1998; Howard, 1997; Michalowicz \& Male, 2011). This researcher argues that these are regarded as non-financial rewards due to lack of better terminology to describe them. Ceteris paribus, demand for so-called nonfinancial rewards by the workers is likely to increase if they do not get adequate financial rewards from their employers. The employer cannot provide these non-financial rewards to the workers free of charge. It is therefore an economic blunder to think that by providing them to the workers, the employer is avoiding financial implications. If workers get adequate financial rewards from their employers, they can get these so-called non-financial rewards on their own thereby increasing intrinsic motivation. For instance, they can acquire their own accommodation or housing, train and develop themselves and create their own good working environment using financial rewards they get from their respective employers.

This researcher concludes that both financial and nonfinancial rewards are important in the world of work as demonstrated by the graphic model displayed in Figure 3. However, the success of an organisation in maintaining the motivational value of both financial and non-financial rewards (whilst improving its performance or productivity) therefore depends on its ability to balance the categories of rewards, including those with no financial implications. These are praise, delegation of work, job enrichment, job enlargement, participation in decision making, appreciation for personal contribution, giving employees a new or improved job title, celebrating the anniversary of their joining the company and a handwritten 'thank you' note (Michalowicz \& Male, 2011).

\section{Discussion}

The aim of the study was to assess the motivational value of rewards amongst health professionals in Malawi's $\mathrm{MoH}$. So far, literature reveals that no consensus has been reached regarding the motivational value of financial and non-financial rewards. As a consequence, organisations are applying theories and models of motivation selectively depending on their beliefs, ideological framework of values and assumptions of variations in the relative importance of rewards at their disposal (Howard, 1997; Torrington et al., 2005).

In this study, the hypothesised model was based on theory and tested by means of correlations through the use of the SEM technique. As explained above, the analysis deleted the 'objectives of a reward system' as a mediating factor. As a consequence, an initial fit of the empirical data on the proposed model was not established. These findings suggest that the objectives of a reward system do not have a mediating effect on the reduction of reward- related problems.
The re-specified model (Figure 2) was also tested using the SEM technique and a reasonable fit was established between the re-specified model and empirical data. The statistical measures that estimated the reasonable fit were NFI, NNFI and CFI. The findings of testing the re-specified model suggest that there are positive causal relationships between financial rewards and reward-related problems faced by health professionals in Malawi's MoH. These findings imply that if the employer increases financial rewards for health professionals, the probability of eliminating reward-related problems increases as well, and vice versa.

The findings displayed in the graphical model (refer to Figure 3) suggest that there is an inverse relationship between financial and non-financial rewards. Thus if financial rewards are increased by the employer, demand for non-financial rewards decreases and vice versa. The rationale behind this inverse relationship is that in the real world of work, ceteris paribus, workers use financial rewards (if they are adequate) to get their non-financial needs or requirements. If financial rewards are not adequate, demand for non-financial needs or requirements from the employer increases. These findings imply that both financial and non-financial rewards are very important in any employment relationship and signify a paradigm shift in the way the motivational value of rewards has been viewed in the field of industrial psychology. Both the re-specified and graphical models symbolise a pragmatic departure from the model of Franco et al. (2004), which leans towards the use of non-financial rewards and suggests that financial rewards should be used with caution.

The findings of this study suggest that financial rewards are motivators amongst health professionals in Malawi's $\mathrm{MoH}$. Although behavioural scientists such as Herzberg (1960, 1966) downplay the use of financial rewards as motivators, they are critical to work motivation especially in the developing countries where the struggle for basic needs (in order to survive) is a reality (Caudron, 1993; Robbins, 2010). These findings do not suggest that non-financial rewards should be completely ignored. They imply that arguments or criticisms against rewards (whether financial or non-financial) should be made with caution because reward preferences vary from individual to individual depending on individual differences and needs as well as the prevailing environmental forces or factors, as suggested by Franco et al.'s (2004) model and supported by the contingency theory of motivation (Blackburn \& Mann, 1979; Bowey, 1997; Landy \& Conte, 2010; White, 1973).

Therefore, this study is, to the researcher's knowledge, one of the first studies to assess the motivational value of rewards amongst health professionals in the public health sector. It is unique in the sense that its findings indicate that both financial and non-financial rewards are indispensable in employment relationships. Furthermore, in the world of work, no relationship exists between rewards, objectives of a reward system and reward-related problems, as manifested by the collapsing of the hypothesised model when an attempt was made to statistically test it. 


\section{Summary of the findings}

\section{Managerial implications and recommendations}

The findings of the hypothesised model suggest to managers and/or policy-makers that the objectives of a reward system have no mediating effect between the rewards and rewardrelated problems faced by health professionals in Malawi's $\mathrm{MoH}$. The finding derived from both re-specified and graphical models symbolise a pragmatic departure from theoretical claims that financial rewards (salaries or money in general) are not a motivator (Herzberg, 1960, 1966). Therefore, although Franco et al.'s (2004) model proposes that financial rewards should be used with caution, this researcher's opinion is that statements about rewards should be made with caution because reward preferences differ from worker to worker amidst various forces operating in the world of work and society as a whole. Rewards (as well as their related practices, systems and strategies) are the major cause of dissatisfaction (and resultantly brain drain) amongst the health professionals in Malawi's MoH because they are perceived by them to be inequitable, inadequate and unfair. The inverse relationship between financial and non-financial rewards that has been graphically demonstrated in Figure 3 is an empirical indication that both financial and non-financial rewards are indispensable in every employment relationship. They are a powerful means of informing workers what is actually valued or not valued in the organisation (Amar, 1994; De Bruyne, 2001; Kapeleta, 2002). Managers and policymakers should always bear in mind that the commitment of health professionals to improving and maintaining quality standards of health care cannot be taken for granted. Offering competitive rewards and ensuring that reward systems and practices are efficient, reasonable, fair, consistent and acceptable to all health professionals is a positive step to attracting and retaining them as well as winning their commitment (Amar, 1994).

\section{Limitations of the study}

The major limitation pertaining to the literature was that there is a massive body of contemporary writing on motivation and rewards. The preferences of the researcher determined the choice of the key texts which, in his view, were relevant to the core theme of the study. For empirical research, behaviour of the respondents, who were systematically sampled for the study, was not directly assessed because the researcher relied solely on the self-administered questionnaire to collect data from them. Consequently, the researcher has failed to articulate the behaviour and attitudes of the respondents during the data collection exercise.

\section{Recommendations for future research}

The first recommendation for future research relates to the inverse (causal) relationship that has been established between financial and non-financial rewards as demonstrated in a graphic model (Figure 3). The graphical model demonstrates that, ceteris paribus, if the employer increases financial rewards, demand for non-financial rewards by workers decreases and vice versa. The researcher is of the view that this model should not be taken lightly by other researchers, scholars, consultants and practitioners since it is not backed up by theory that is mostly founded on Western studies. Further empirical research is recommended to re-test the model in the public health sectors of developing countries with other samples.

The second recommendation relates to the view that financial rewards are of primary importance (compared to non-financial rewards) in any employment relationship in the developing countries since the reciprocity principle of the contract of employment states that workers are entitled to financial rewards when they have placed their labour services at the disposal of an employer (Basson et al., 2002; Finnemore, 2002). Presently there is a pool of empirical research findings that organisations can succeed in motivating their workers and improving their productivity through the use of financial rewards only. However, no empirical evidence is readily available supporting the argument that through the use of only non-financial rewards, organisations can succeed in motivating their workers and improving their productivity. Plainly speaking, the motivational value of non-financial rewards has been praised in the context where financial rewards have not been completely ignored (Dewhurst, Guthridge \& Mohr, 2009; Silverman, 2004). It is therefore recommended further that scientifically informed research should be conducted to bring to light examples of wellestablished business organisations in developing countries whose workers have only non-financial reward packages governing their contracts of employment.

A comparative analysis of performance of the two categories of business organisations (that is those whose workers only have financial reward packages governing their contracts of employment and those whose workers only have nonfinancial reward packages governing their contracts of employment) should also be done and reported on to end the debate.

The third and final recommendation relates to this researcher's belief that a candle does not lose anything by lighting another candle. The researcher is convinced that 'praise' or 'thank you' as a form of recognition, positive feedback, participative decision-making, job autonomy, delegation, job enlargement and job enrichment are unquestionably non-financial rewards. However, inspired scientific clarifications should be made (through scientifically informed research) by the proponents of non-financial rewards on how other alleged non-financial rewards (especially career advancement, housing or accommodation or shelter, training and development promotional opportunities, company car, good working environment, club membership, and annual award ceremonies to recognise employees' contributions) can be provided by an employer without financial implications attached to them. Otherwise the researcher is of the view that these non-financial rewards are basically financial rewards offered to health professionals (or any workers) in a disguised form. 


\section{Conclusion}

From the above discussions and debates, it is clear that a lot has been said, written and talked about regarding the motivational value of rewards in the field of industrial and organisational psychology. What is indisputable is that rewards are indispensable in every employment relationship. Offering competitive rewards and ensuring that reward systems and practices are efficient, reasonable, fair, consistent and acceptable to all health professionals is a positive step to attracting and retaining them, and ultimately winning their commitment (Amar, 1994; Dieleman, Cuong, Anh \& Martineau, 2003; Kapeleta, 2002).

\section{Acknowledgements}

The research findings reported in this article are the product of a doctoral thesis for Alfred W.D. Chanza at Nelson Mandela Metropolitan University (NMMU). Financial support (in the form of publication fees) from NMMU and permission by National Health Sciences Research Committee (NHSRC) to conduct the study in Malawi's MoH, are hereby acknowledged. Conclusions drawn or opinions expressed in this article are those of the authors and do not necessarily reflect the views of NMMU.

\section{Competing interests}

The authors declare that they have no financial or personal relationship(s) which may have inappropriately influenced them in writing this article.

\section{Authors' contributions}

A.W.D.C. (Nelson Mandela Metropolitan University) conducted the research as part of his doctoral studies and wrote most of the article's content. R.J.S. (Nelson Mandela Metropolitan University) was the promoter while G.J.L. (Nelson Mandela Metropolitan University) was the copromoter for the study. The two research experts also made significant contributions in conceptualising, writing and presenting this article.

\section{References}

Ader, H.J., \& Mellenbergh, G.S. (2008). Advising on research methods: A consultant companion. Huizen: Johannes van Kessel Publishing.

Agnew, J.L., \& Redman, W.K. (1992). Contingency specifying stimuli. The role of rules in organisational behaviour management. Journal of Organisational Behaviour Management, 12(2), 67-76. http://dx.doi.org/10.1300/J075v12n02_04

Ahlegren, A., Anderson, I., \& Skold, H. (2007). Individual versus team-based reward systems. Goteborg: School of Business Economics and Law.

Alston, M., \& Bowles, W. (1998). Research for social workers: An introduction to research methods. Sydney: Allen \& Unwin.

Amar, A.D. (1994). Motivating workers in 1990s: Reward and recognition. Mid-Atlantic Journal of Business - High Beam Research, June, 1994.

Arliely, D., Greezy, U., Lowenstein, G., \& Major, N. (2005). Behavioural economics. Boston: Federal Reserve Bank.

Armstrong, M. (1993). Managing reward systems. Buckingham: Open University Press.

Armstrong, M. (1999). A handbook of human resource management. (7th edn.) London: Kogan Page.

Armstrong, M. (2010). Amstrong's handbook on reward management practice Improving performance through reward. London: Kogan Page.

Armstrong, M., \& Murlis, H. (1998). Reward management. A handbook of reward strategy and practice. London: Kogan Page.
Armstrong, M., \& Murlis, H. (2007). Reward management: A handbook of reward strategy and practice. (5th edn.). London: Kogan Page.

Babbie, E. (2005). The basics of social research. (3rd edn.). Toronto: Thomson Wadsworth.

Babbie, E. (2007). The practice of social research. (11th edn.). London: Oxford University Press.

Babbie, E., \& Mouton, J. (2001). The practice of social research. London: Oxford University Press. PMid:11247957

Bagozzi, R.Y. (2012). Specification, evaluation and interpretation of structural equation models. Journal of the Academy of Marketing Science, 40(1), 8-34. http://dx.doi. org/10.1007/s11747-011-0278-x

Baron-Punda, M. (2002). Modelling and simulation of the labour cost in unit and small batch production. Retrieved May 05, 2010, from http://www.stroj.uccsk/journal/ eng/papers024-2002pdf

Barry, C.A. (1998). Choosing qualitative data analysis software. Retrieved July 15 2010, from http://www.socreonlineorg.uk

Basson, A., Christianson, M., Garbers, C., Le Roux, P., Mischke, C., \& Strydon, E. (2002). Essential labour law. (3rd edn.). Houghton: Labour Law Publications.

Beardwell, I., \& Holden, L. (2001). Human resource management: A contemporary approach. (3rd edn.). Englewood Cliffs, NJ: Prentice Hall.

Bentler, P.M., \& Bonnet, D.G. (1980). Significance tests and goodness of fit in the analysis of covariance structures. Psychological Bulletin, 88, 588-606. http:// dx.doi.org/10.1037/0033-2909.88.3.588

Bentler, P.M. (1980). Multivariate analysis with latent variables: Causal modeling Annual Review of Psychology, 31, 11-21. http://dx.doi.org/10.1146/annurev. ps.31.020180.002223

Bentler, P.M. (1990). Comparative fit indices in structural models. Psychological Bulletin, 107, 238-346. http://dx.doi.org/10.1037/0033-2909.107.2.238, PMid:2320703

Berger, L.A., \& Berger, D.R. (2000). The Compensation handbook: A state-of-the art guide to compensation strategy. (4th edn.). New York: McGraw-Hill.

Berry, D.M. (2003). An evaluation of mentoring to develop a strategy for facilitating the objectives of the Employment Equity Act (Act 55 of 1998). Unpublished manuscript.

Bowey, A.M. (1997). Motivation at work. London: Macmillan.

Bowey, A.M., Thorpe, R., \& Hellier, P. (1986). Payment systems and productivity. London: Macmillan. PMid:3804023, PMCid:PMC1433974

Bowie, C., Mwase, T. \& Chinkhumba, J. (2009). Health workers' income and expenditure in Malawi: An assessment of the relative contribution of incentive schemes to take home pay and the extra living costs of rural posts. Blantyre: COM.

Brace, N., Kemp, R., \& Snelgar, R. (2000). SPSS for psychologists: A guide to dato analysis using SPSS for Windows. New York: Palgrave.

Bratton, J., \& Gold, J. (1999). Human resource management theory and practice. (2nd edn.). London: Macmillan.

Bryman, A., \& Cramer, D. (1999). Quantitative data analysis with SPSS Release 8 for Windows: A guide to social scientists. New York: Routledge.

Burns, T., \& Stalker, G. (1961). The management of innovation. London: Tavistock.

Burns, N., \& Grove, S.K. (2009). The practice of nursing research: Appraisal, synthesis and generation of evidence. (6th edn.). St Louis: Elsevier.

Burns, R. (2000). Introduction to research methods. London: Sage.

Caudron, S. (1993, 15 November). Motivating? Money's only no. 2. Industry Week, p. 33.

Carrel, M.R., Elbert, N.F., Hatfield, R.D., Grobler, P.A., Marx, M., \& Van der Schyf, S. (1998). Human resource management in South Africa. Englewood Cliffs, NJ: Prentice Hall.

Chapalapata, M. (2011, 4 March). Civil servants open bank accounts. The Daily Times, p. 3.

Chapulapula, T. (2011, 24 March). ACB to prosecute creators of ghost workers. The Daily Times, p. 3.

Cherrington, D.J. (1995). Management of human resources. Englewood Cliffs, NJ: Prentice-Hall.

Clarke, L. (1995). Nursing research: Science visions and telling stories. Journal of Advanced Nursing, 21(3), 584-593. http://dx.doi.org/10.1111/j.1365-2648.1995. tb02744.x, PMid:7745215

Cole, G.A. (2004). Management theory and practice. (6th edn.). London: Thomson Learning.

Cole, G.A. (2000). Management theory and practice. (5th edn.). London: Thomson Learning.

Collis, J., \& Hussey, R. (2003). Business research: A practical guide for undergraduate and postgraduate studies (2nd edn.). New York: Macmillan. PMCid:PMC1125672

Costley, D.L., Melgoza, C.S., \& Todd, R. (2000). Human relations in organisations. (5th edn.). New York: West Publishing Company.

David, M., \& Sutton, C.M. (2004). Social research: The basics. London: Sage.

Decker, I. (1997). Research sampling. Flagstaff, AZ: Northern Arizona University.

De Bruyne, J.W. (2001). A study to identify the factors responsible for job dissatisfaction and low teacher morale. Retrieved September 18, 2011, from http://www. uwstout.edu/lib/thesis/2001.

Denzin, N.K., \& Yvonnas, L. (2005). Handbook of qualitative research. (3rd edn.). London: Sage. PMCid:PMC1088373 
Dittrich, J.E., \& Carrel, M.R. (1979). Organisational equity, perceptions, employee job satisfaction and departmental absence and turnover rates. Organisational Behaviour and Human Performance, 24, 29-40. http://dx.doi.org/10.1016/0030Behaviour and Humd
5073(79)90013-8

Dieleman, M., Cuong, P.V., Anh, L.V., \& Martineau, T. (2003). Identifying factors for job motivation of rural health workers in North Vietnam. http://www.humanresources-health.com/content/1/1/10 Retrieved June 18, 2010, from http:// resources-health.com/content/1/1/10 Retriev
www.human-resources-health.com/content

Dovlo, D. (2004). Wastage in the health workforce: Some perspectives from African countries. Retrieved July 10, 2010, from http://www.ncbi.nlm.nih.gov/pmc/ articles/PMC1198245/

Dovlo, D. (2003). Brain drain and retention of health professionals in Africa. Retrieved April 03, 2011, from http://www.hrhresource.centre.org/note/445

DSS Research (2001). Sampling error. Retrieved June 18, 2010, from http://www. dssresearch.com/general/sampling.asp

Duncan, K.D., Gruenburg, M.M., \& Wallis, D. (1980). Changes in working life. London: Wiley.

Dzimbiri, L.B. (2009). Organisation and management theories: An African focus. Cuvillier Verlag Gottingen: International Scientific Publishers.

Dzimbiri, L.B. (2008). Industrial relations in a developing society: The case of colonial, independent one-party and multi-party Malawi. Cuvillier Verlag Gottingen: International Scientific Publishers.

Dyer, L., Schwab, D.P., \& Fossum, J.A. (1978). Impacts of pay on behaviours and attitudes: An update. Personnel Administrator, 23, 51-53. PMid:10305700

Eddy, A. (2008). Designing a reward system. Phoenix, AZ: Axia College of the University of Phoenix.

Ederer, F.P., \& Manso, G. (2010). Is pay-for-performance detrimental to motivation? Retrieved May 03, 2011, from http://www.ssrn.com/abstract

Dewhurst, M., Guthridge, M., \& Mohr, E. (2009). Motivating people: Getting beyond money. Retrieved June 17, 2010, from http://www.mckinseyquarterly.com/ Motivating_people_Getting_beyond_money_2460

Fabrigar, L.R., Wegener, D.T., MacCallum, R.C., \& Straham, E.J. (1999). Evaluating the use of exploratory factor analysis in psychological research. Journal of Industrial use of exploratory factor
Psychology, 4, 472-499.

Fan, X., Thompson, B., \& Wang, L. (1999). Estimation methods and model specifications on SEM fit indices. Psychological Bulletin, 6, 56-83.

Ferber, M.A., \& Nelson, J.A. (2009). Beyond economic man: Feminist theory and economics. Chicago: The University of Chicago Press.

Finnemore, M. (2002). Introduction to labour relations in South Africa. (8th edn.) Durban: Butterworth.

Fowler, A. (1996). How pick a job evaluation system. People Management, 2, 42-43.

Franco, L., Bennett, S., \& Kanfer, R. (2002). Health sector reform and public sector health worker motivation: A conceptual framework. Social Science and Medicine, 54(8), 1255-1266. http://dx.doi.org/10.1016/S0277-9536(01)00094-6

Franco, L., Bennett, S., Kanfer, R., \& Stubblebine, P. (2004). Determinants and consequences of health worker motivation in hospitals in Jordan and Georgia.
Social Science and Medicine, 58, 343-355. http://dx.doi.org/10.1016/S0277Social Science and
9536(03)00203-X

Franco, L., Bennett, S., Kanfer, R., \& Stubblebine, P. (2000). Health worker motivation in Jordan and Georgia. A sythensis of results. Bethesda: MD Partnersips for Health Reform Project.

Gellerman, S. (1963). Motivation and personality. New York: American Management Association. PMid:14094055

George, D., \& Mallery, P. (2003). SPSS for Windows step by step: A Simple guide and reference. (4th edn.). Boston: Allyn \& Bacon.

Gliem, J.A., \& Gliem, R.R. (2002). Calculating, interpreting and reporting Cronbach's alpha reliability coefficient for Likert-type scales. Columbus: Ohio State University.

Goldberger, A.S. (1972). Structural equation models in social sciences. Econometrica, 40, 479-1001. http://dx.doi.org/10.2307/1913851

Goldthorpe, J. (1986). The affluent worker. London: Cambridge University Press.

Gordon, M. (2008). Malawi emergency human resources programme: An overview. Lilongwe: DFID.

Gorsuch, R.L. (1983). Factor analysis (2nd edn.). Mahwah, NJ: Earlbaum Associates. PMCid:PMC1001136

Greene, J.C., Caracelli, V.J., \& Graham, W.F. (1989). Towards a conceptual framework for mixed-method evaluation designs. Educational evaluation and policy analysis, $11(3), 255-274$

Greenfield, F. (1993). Money: The motivator of the 90s. Pretoria: Southern Book Publishers.

Grobler, P.A., Warnich, S., Carrell, M.R., Elbert, N.F., \& Hatfield, R.D. (2006) Human resource management in South Africa. London: Thomas Learning. Human resource mon
PMCid:PMC1422768

Herzberg, F. (1966). Work and the nature of man. Cleveland: World Publishing.

Herzberg, F. (1960). Motivation to work. In F. Herzberg (1966). Work and the nature of man. Cleveland: World Publishing.

Holbeche, L. (2010). Aligning human resources and business strategy. London: Butterworth. PMid:20422809

Hooper, D. (2008). Statistical equation modeling: Determining the model fit. Retrieved July 12, 2012, from http://www.hooper/SEM/arrow/html
Howard, F. (1997). Keeping the best employees in the 90s. The Journal of Property Management, 62(3), 20-25.

Kanfer, R. (1992). Work motivation: New directions in theory and research. International Review of Industrial and Organizational Psychology, 7, 2-53.

Kapeleta, A.B.K. (2002). Human relations. Blantyre: Staff Development Institute. Unpublished manuscript.

Kenny, D.A. (2011). Re-specification of latent variable models. Retrieved July 12, 2012, from http://www.davidkenny/respec.htm

Kerlinger, F.N., \& Lee, H.B. (2000). Foundations of behavioural research (4th edn.). London: Thomson Learning.

Khunga, S. (2011, 22 March). Government loses K2bn to ghosts. The Daily Times, p. 1.

Kim, J.O., \& Mueller, C.W. (1978). Introduction to factor analysis. London: Sage.

Kim, Y.Y. (1995). Cross-cultural adaptation: An integrative theory. In R.L. Wisemen (Ed). Inter-cultural communication theory (pp. 170-194). Thousand Oaks, CA: Sage.

Korb, K.A. (2012). Conducting educational research. Retrieved May 11, 2012, from http://www.korbpsychology.com

Koala Consulting and Training (2008). Reward systems. Retrieved February 20, 2010, from http://www.koalacat.com

Landy, F.J., \& Conte, J.M. (2010). Work in the 21st Century. An Introduction to Industria and Organizational Psychology. (3rd edn.). New York: John Wiley and Sons.

Ledford, G.E. (2008). Factors affecting the long-term success of skill-based pay. WorldatWork. PMCid:PMC2784638

Losh, S.C. (2002). Methods of educational research, Fall 2002. Guide 2: Variables and hypotheses. Retrieved May 12, 2012, from http://www.mailer.fsu.edu/slosh/ methodsguide $2 \mathrm{html}$

Luczak, H. (1998). Arbeitswissenschaft. Berlin: Springer. PMid:9442046

Malawi Government (2007). Malawi Health SWAp. Lilongwe: $\mathrm{MoH}$.

Manafa, O., McAuliffe, A., Maseko, F., Bowie, C., MacLachlan, M., Normand, C., \& Chirwa, M. (2009). Retention of health workers in Malawi: Perspectives of health workers and district management. Human Resources for Health, 10, 7-25.

Mangham, L. (2007). Addressing the human resource crisis in Malawi's Health Sector: Employment preferences of public sector registered nurses. London: ESAU Economic and Statistical Analysis Unit.

Maslow, A.H. (1943). A theory of human motivation. Psychological Review, 50, 370396. http://dx.doi.org/10.1037/h0054346

Mathauer, I., \& Imhoff, I. (2006). Health worker motivation in Africa. The role of nonfinancial rewards and human resource management tools. Human Resources for Health, 4, 24-25. http://dx.doi.org/10.1186/1478-4491-4-24, PMid:16939644, PMCid:PMC1592506

McAuliffe, E., Bowie, C., Munafa, O., Maseko, F., MacLachlan, M., Hevey, D., Normand, C., \& Chirwa, M. (2009). Understanding job satisfaction amongstst mid-level C., \& Chirwa, M. (2009). Understanding job satisfaction amongstst mid-level
cadres in Malawi: The contribution of organisational justice. Human Resources for Health, 2009, 7-13.

Metcalf, H. (1995). Future skills demand and supply: Trends, shortages and gluts. London: PSI Publications.

Michalowicz, M., \& Male, B. (2011). 51 ways to reward employees without money. Retrieved August 21, 2012, from http://www.goodnewsaday.worldpress/ content $/ 7 / 1 / 6$

Ministry of Development Planning and Cooperation. (2010). Malawi Millennium Development Goals Report. Lilongwe: MEPD.

Ministry of Health (2010). Human resource crisis in the health sector. Towards a solution. Lilongwe: $\mathrm{MoH}$.

Mouton, E.B.J. (2009). The practice of social research. Oxford: Oxford University Press.

Mphande, J. (2011, 17 March). The opportunity cost of ghost workers. The Sunday Times, p. 7.

Mtazu, P.S. (2009). Evaluating remuneration and reward systems at Lobels Bread in Zimbabwe. PE: NMMU.

Mullins, L.J. (1996). Management and organisational behaviour. (4th edn.). London: Pitman Publishing.

Munthali, K. (2011, 22 March). Ghost workers drain K2bn per year. The Nation, p. 1.

Musa. M. (2011, 7 March). The new system affects government salaries. Daily Times, p. 2.

Muula, A.S. (2006). Shortage of health workers in Malawi Public Service System: How do parliamentarians perceive the problem? African Journal of Health Sciences, 13, 124-130. PMid:17348752

Muula, A.S., \& Maseko, F.C. (2005). Survival and retention strategies for Malawi health professionals. EQINET Discussion Paper No. 32. Retrieved June 11, 2010, from http://www.humanresource.com/content/7/1/6

Mzungu, W. (2011, 4 April). Fraud hits government clinics. The Sunday Times, p. 3.

National Statistical Office (2008). Population and housing census. Zomba: NSO.

Nicoll, L.H., \& Beyea, S.C. (1997). Selecting research instruments to measure the reliability and validity of nursing studies. Retrieved May 14, 2012, from http:// reliability and validity of nursing studies. Ret
www.researchinstruments/nicoll/beyea/html

Njiragoma, W. (2011, 9 May). New system of salary payments. The Daily Times, p. 4.

Oliver, P. (2010). Understanding the research process. London: Sage.

Palmer, D. (2006). Tackling Malawi's human resource crisis. Reproductive Health Matters, 14, 27-39. http://dx.doi.org/10.1016/S0968-8080(06)27244-6 
Paradath, A., Chamberlain, C., McCoy, D., Ntuli, A., Rowson, M., \& Loewenson, R. (2003). Health personnel in Southern Africa: Continuing maladistribution and brain drain. Harare: EQUINET.

Pearce, J.L. Branyiczki, I., \& Bakacsi, G. (1994). Person-based reward system: A theory of organisational reward practices in reform communist organisations.
Journal of Organisational Behaviour, 15(3), 261-282. http://dx.doi.org/10.1002/ job.4030150307

Pearl, J. (2000). Causality: Models, reasoning and inference. London: Cambridge University Press.

Phiri, N.A. (2007). Does training in surgical skills of clinical officers in the Southern Region reduce number of surgical referrals from district government and CHAM hospitals to central hospitals? Blantyre: COM.

Podger, M. (2002). Performance management. Retrieved March 08, 2011, from http:// www.apsc.gov.au/publications02/performancemanagement.htm

Polit, D.F., \& Hungler, B.P. (1999). Nursing research principles and methods. (5th edn.) Philadelphia: Lippincott Company. PMid:10482253

Ratner, B. (2011). Workforce optimisation. New York: DM Stat Consulting.

Redmond, B.F. (2010). Needs theories. What do I want when I work? Work attitudes and motivation. Pennsylvania: The Pennsylvania State University World Campus.

Reid, G.J. (2007). Public administration salary setting principles and mechanisms for satisfying them. Retrieved April 03, 2011, from http://www.site.worldbank.org/ Administrationsalarysetting.pdf

Respondanet. (2010). Corruption in the Health Sector. Retrieved June 10, 2011, from http://www.respondanet.com/index.php

Robbins, S.P. (2010). Organisational behaviour. (10th edn.). Englewood Cliffs, NJ: Prentice-Hall.

Robbins, S.P., Odendaal, A., \& Roodt, G. (2005). Organisational behaviour. Cape Town: Prentice Hall.

Routio, P. (2007). Models in the research process. Retrieved April 17, 2012, from http://www.uiah.fi/projects/methods.html

Rynes, S.L., \& Gerhart, B. (2001). Compensation in organisations. San Francisco: JossyBass. PMid:11761600

Salkind, N.J. (2000). Exploring research. (4th edn.). London: Prentice-Hall.
Silverman, M. (2004). Non-financial recognition: The most effective of rewards? Brighton: IES.

Singh, P., Das, G.S., \& Dileep, K.M. (2006). Strategies to reduce perceptional gap on reward management system. Academic Management Journal, 54(3), 38-74.

Snelgar, R.J. (2012). The reward preferences/motivation: Paradox and implication for performance and education. Port Elizabeth: NMMU.

Sonani, B. (2011, 6 May). Dowa District Hospital staff strike. The Nation, p. 3.

Sparrow, P. (1996). Too good to be true? People Management, 22-27.

Stanley, J.D., \& Berger, M.C. (1965). Employee reward and incentives. London: ICWA.

Steven, W. (1991). Model briefing and a definition of science. Journal of Research in Science Teaching, 28(1), 73-79. http://dx.doi.org/10.1002/tea.3660280107

Stevens, J. (1996). Applied multivariate statistics for social sciences (3rd edn.). Mahwah, NJ: Earlbaum Associates.

Swanepoel, B., Erasmus, B., Van Wyk, M., \& Schenk, H. (2005). South African human resource management: Theory and practice. (3rd edn.). Cape Town: Juta.

Taylor, F.W. (1947). Scientific management. New York: Harper \& Row.

Tenthani, R. (2002). Malawi's civil servants faced gloomy Christmas without pay as government funds ran out. Retrieved November 10, 2010, from http://www. capetimes.co.za/index.php?fArticleld

Torrington, D., Hall, L., \& Taylor, S. (2005). Human resource management. (6th edn.). London: Prentice-Hall.

Van Klaveren, M., Tijdens, K., Hughie-Williams, M., \& Martin, N.R. (2009). An overview of women's work and employment in Malawi: Decisions for life MDG3 Project Country Report No. 6. Amsterdam: University of Amsterdam.

Weber, M. (1947). The theory of social and economic organisation. Glencoe: Free Press.

White, M. (1973). Motivating managers financially. London: IPM.

Wikipedia. (2012). Factor analysis. Retrieved April 08, 2012, from http://www. en.wikipedia.org/wiki/factor_analysis

Woodward, J. (1958). Management and technology. London: HMSO.

World Bank. (2004). Human resources and financing for the health sector. Lilongwe: World Bank. 